Supplement of Biogeosciences, 15, 1683-1700, 2018

https://doi.org/10.5194/bg-15-1683-2018-supplement

(C) Author(s) 2018. This work is distributed under

the Creative Commons Attribution 4.0 License.

(c) (1)

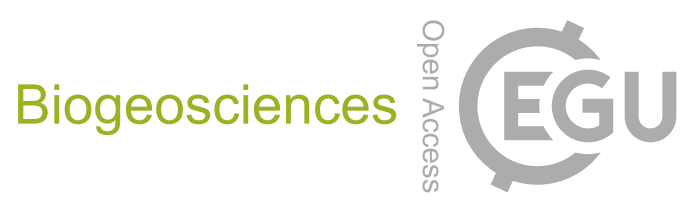

Supplement of

\title{
A comprehensive biogeochemical record and annual flux estimates for the Sabaki River (Kenya)
}

Trent R. Marwick et al.

Correspondence to: Trent R. Marwick (trent.marwick@gmail.com)

The copyright of individual parts of the supplement might differ from the CC BY 4.0 License. 
Table S1. Bi-weekly monitoring data, Sabaki River: Overview of lower and upper discharge (LDE and UDE, respectively) estimates, surface water temperature ( $\mathrm{T})$, $\mathrm{pH}$, percent dissolved oxygen (\%), conductivity (Cond.), total alkalinity (TA), concentration of total suspended matter (TSM) and the contribution of particulate organic carbon (POC) to the TSM load (\%POC), concentrations and carbon (C) stable isotope signatures of POC ( $\left.\delta^{13} C_{P O C}\right)$ and dissolved organic $\mathrm{C}$ (DOC and $\delta^{13} \mathrm{C}_{\mathrm{DOC}}$, respectively), concentration and nitrogen $(\mathrm{N})$ stable isotope signature of particulate $\mathrm{N}$ (PN and $\delta^{15} \mathrm{NPN}$ ), concentration of total particulate phosphorus (TPP), dissolved methane $\left(\mathrm{CH}_{4}\right)$ and nitrous oxide $\left(\mathrm{N}_{2} \mathrm{O}\right)$ concentrations and \% saturation, and concentrations of ammonium $\left(\mathrm{NH}_{4}{ }^{+}\right)$, nitrate $\left(\mathrm{NO}_{3}{ }^{-}\right)$, and phosphate $\left(\mathrm{PO}^{3-}{ }^{3-}\right.$.

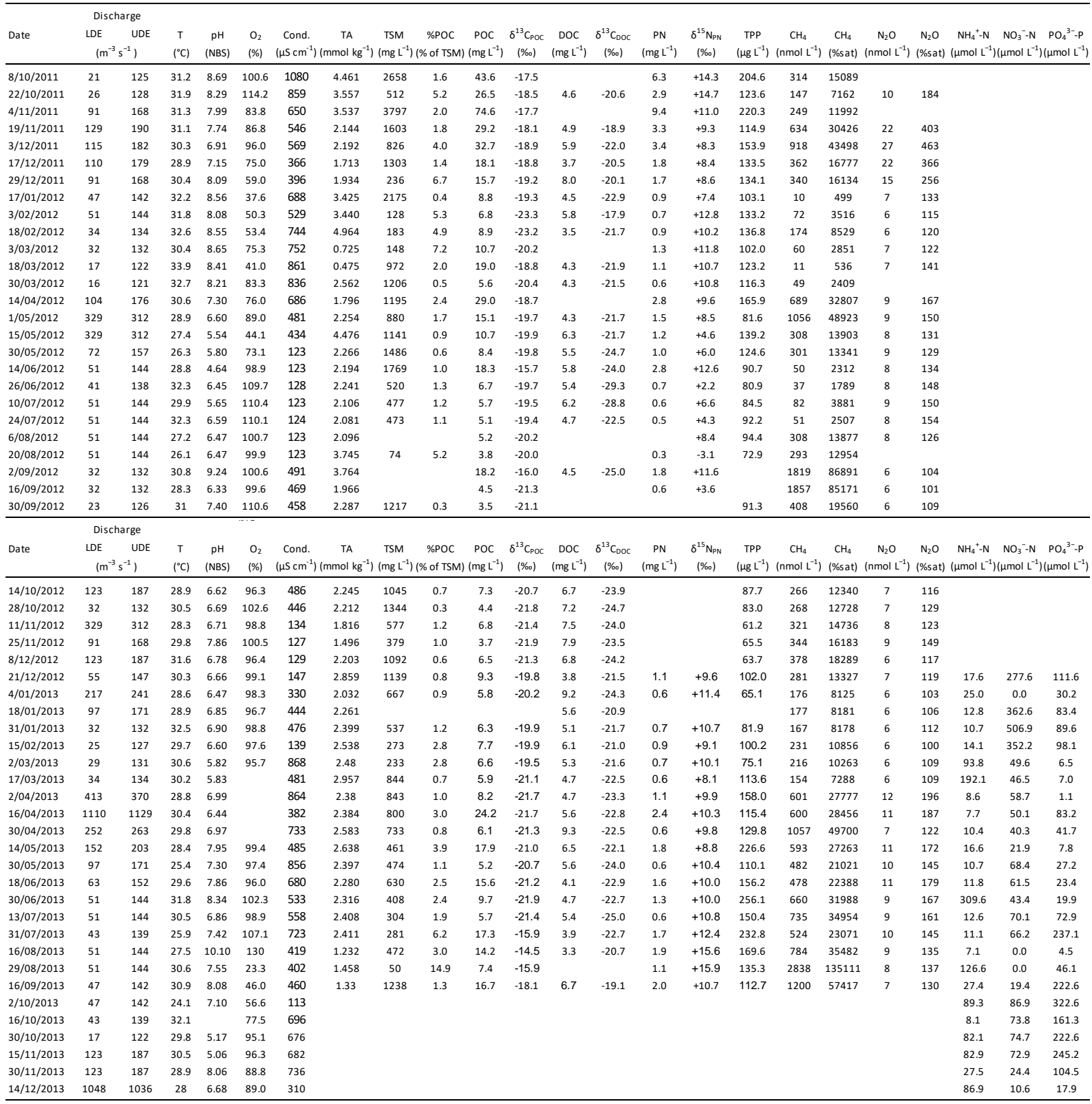


Table S2. Annual fluxes and yields for lower and upper discharge estimates (LDE and UDE, respectively) from the Athi-Galana-Sabaki river basin. Mean annual discharge rates are presented with median values in closed brackets. Measured parameters include total suspended matter (TSM), particulate and dissolved organic carbon (POC and DOC, respectively), particulate nitrogen and organic phosphate (PN and POP, respectively), dissolved nutrient fractions of ammonium $\left(\mathrm{NH}_{4}{ }^{+}\right)$, nitrate $\left(\mathrm{NO}_{3}{ }^{-}\right)$, and phosphorus $\left(\mathrm{PO}_{4}{ }^{3-}\right)$, as well as the proportional contribution of POC to the TSM pool, and likewise DOC to the total organic carbon pool, and the ratio of POC to PN.

\begin{tabular}{|c|c|c|c|c|}
\hline & \multicolumn{2}{|c|}{$2011-2012$} & \multicolumn{2}{|c|}{$2012-2013$} \\
\hline & LDE & UDE & LDE & UDE \\
\hline Discharge $\left(\mathrm{m}^{3} \mathrm{~s}^{-1}\right)^{a}$ & $140(51)$ & $228(144)$ & $138(55)$ & $218(147)$ \\
\hline Discharge $\left(\mathrm{m}^{3} \mathrm{~s}^{-1}\right)^{b}$ & & & $161(51)$ & $237(144)$ \\
\hline Flux & \multicolumn{4}{|c|}{$\left({\left.\operatorname{Tg~} y r^{-1}\right)}^{-1}\right.$} \\
\hline \multirow[t]{2}{*}{ TSM } & 4.7 & 7.5 & 3.2 & 4.9 \\
\hline & \multicolumn{4}{|c|}{$\left(G g y^{-1}\right)$} \\
\hline POC & 85.51 & 129.85 & 55.72 & 81.26 \\
\hline DOC & 21.79 & 35.51 & 26.49 & 40.51 \\
\hline PN & 9.01 & 13.96 & 6.03 & 8.96 \\
\hline POP & 0.53 & 0.86 & 0.53 & 0.84 \\
\hline $\mathrm{NH}_{4}^{+}$ & & & 2.31 & 4.11 \\
\hline $\mathrm{NO}_{3}^{-}$ & & & 4.33 & 7.74 \\
\hline $\mathrm{PO}_{4}^{3-}$ & & & 11.15 & 18.66 \\
\hline \%POC (of TSM) & 1.8 & 1.7 & 1.7 & 1.7 \\
\hline POC:PN & 9.5 & 9.3 & 9.2 & 9.1 \\
\hline$\% \mathrm{DOC}$ (of TOC) & 20 & 21 & 32 & 33 \\
\hline Yield & \multicolumn{4}{|c|}{$\left(\mathrm{Mg} \mathrm{km}^{-2} \mathrm{yr}^{-1}\right)$} \\
\hline TSM & 100.70 & 159.73 & 68.44 & 104.11 \\
\hline POC & 1.83 & 2.78 & 1.19 & 1.74 \\
\hline \multirow[t]{2}{*}{ DOC } & 0.47 & 0.76 & 0.57 & 0.87 \\
\hline & \multicolumn{4}{|c|}{$\left(\mathrm{kg} \mathrm{km}^{-2} \mathrm{yr}^{-1}\right)$} \\
\hline PN & 192.6 & 298.7 & 129.0 & 191.6 \\
\hline POP & 11.4 & 18.4 & 11.4 & 18.0 \\
\hline $\mathrm{NH}_{4}^{+}$ & & & 49.4 & 87.8 \\
\hline $\mathrm{NO}_{3}^{-}$ & & & 92.7 & 165.6 \\
\hline $\mathrm{PO}_{4}{ }^{3-}$ & & & 238.5 & 399.2 \\
\hline
\end{tabular}

${ }^{a}$ All fractions except dissolved $\mathrm{N}$ and P: hydrological years $1^{\text {st }}$ October 2011 to $30^{\text {th }}$ September 2012 and $1^{\text {st }}$ October 2012 to $30^{\text {th }}$ September 2013.

${ }^{b}$ Dissolved N and P only: hydrological year 21 ${ }^{\text {st }}$ December 2012 to $14^{\text {th }}$ December 2013. 

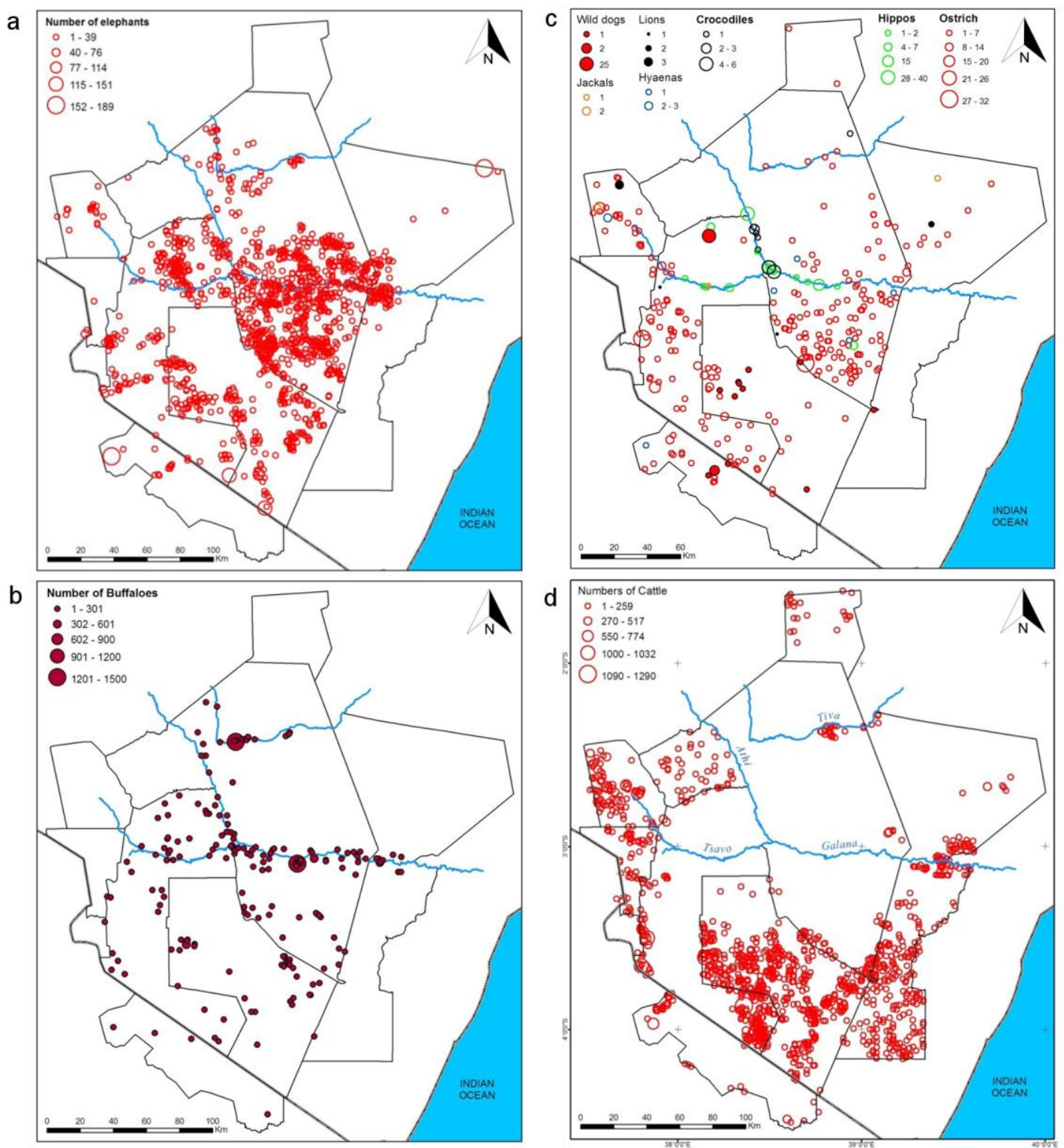

Figure S1. Aerial census results for large mammals in the Tsavo-Mkomazi ecosystem, including (a) elephants, (b) buffalo, (c) hippopotami and other wildlife, and (d) cattle. The blue line represents rivers, with the Athi, Tsavo, and Galana rivers labelled in (d). (adapted from Ngene et al. (2011)). 